\title{
ВИКОРИСТАННЯ ФУНКЦЙ УОЛША-АДАМАРА ДЛЯ ЗАХИСТУ ІНФОРМАЦІЇ ПІД ЧАС ЇЇ ПЕРЕДАВАННЯ КАНАЛАМИ ЗВ'ЯЗКУ
}

В теперішній час у зв'язку з формуванням широких комп'ютерних інформаційних мереж, розрахованих на зберігання та передавання конфіденційної інформації, розвитку електронних пошт, систем банківських електронних платежів тощо, виникає потреба у забезпеченні захисту інформації. Заходи захисту інформації можна розподілити на

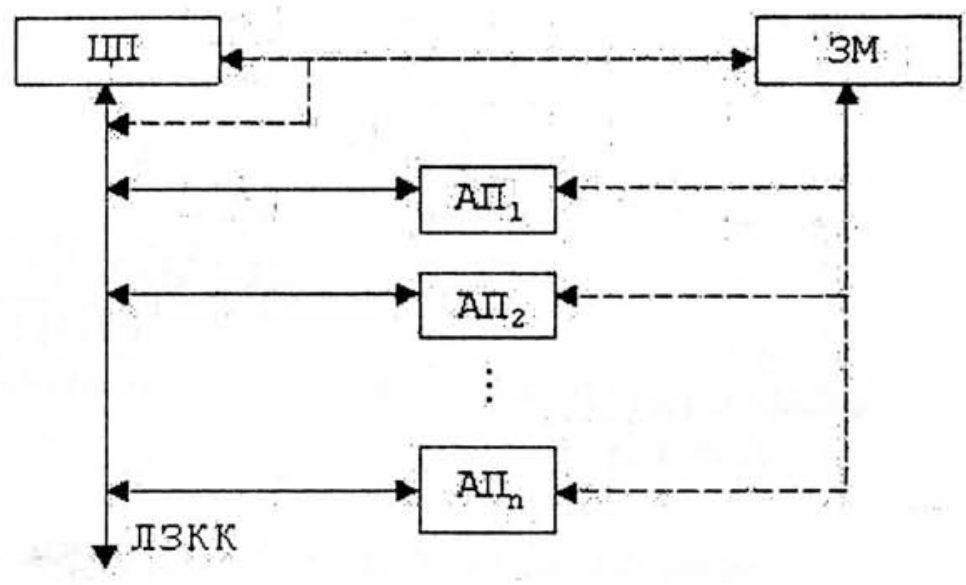

Рисунок 1 - Узагальнений вигляд системи передавання інформації: ЦП - центральний пункт зв'язку; АП $\mathrm{n}-\mathrm{n}$-ний абонентський пункт; ЗМ - зловмисник; ЛЗКК - лінія зв'язку колективного користування'. організаційні та технічні [1]. Умовно систему передавання інформації в узагальненому вигляді можна зобразити у вигляді, поданому на рисунку 1. Більшість таких систем використовують лінії зв'язку колективного користування. Саме вони і $\epsilon$ найбільш вразливим елементом у системі передавання. Якщо можливий несанкціонований доступ до інформації на центральному пункті зв'язку чи на абонентських пунктах, то саме розроблення системи передавання не має сенсу. Виходячи 3 цього, їх можна вважати абсолютно надійними.

$\begin{array}{crr}\text { Одним } 3 & \text { найбільш } \\ \text { важливих аспектів у галузі }\end{array}$ передавання інформації $є$ її захист як від завад у каналі зв'язку, так і від несанкціонованого доступуу у випадку їі конфіденційності. Найбільш поширений підхід полягає у криптографічному закритті інформації, а потім перетворенні за допомогою завадозахищених кодів. Разом з тим самі алгоритми завадозахищеного кодування вже вміщують елементи криптографічного закриття інформації.

Побудова засобів передавання на базі мікропроцесорної техніки накладає власні обмеження на розроблювані алгоритми кодування. Пристрої обміну інформацією будуються за класичною структурою, схема якої наведена на рисунку 2.

Основна особливість таких пристроїв полягає в тому, що дані зберігаються i передаються в байтовому форматі. Тобто, незалежно від довжини елементарного повідомлення послідовні інтерфейси передають повідомлення фіксованої довжини (вісім двійкових розрядів). Якщо довжина елементарного повідомлення менша, то пристрій сам доповнює повідомлення нулями і лише після цього передає його до каналу зв'язку. Побудова алгоритмів завадозахищеного кодування вимагає врахування співвідношень інформаційних i контрольних розрядів з метою знаходження оптимального режиму передавання: мінімальний обсяг даних - мінімальний час передавання - максимальна ефективність використання каналу 3 одного боку і максимальна кодова відстань - максимальний захист від завад 3 іншого. Певні спроби проаналізувати алгоритми завадозахищеного кодування в цьому аспекті вже здійснювались $[2,3]$. При цьому розглядались найбільш поширені 3 них: код Хеммінга та циклічний, оскільки вони найбільш просто алгоритмізуються і дозволяють 
здійснювати кодування та декодування в програмному режимі $[4,5]$. При цьому сумарна кількість символів буде визначатися:

$$
\mathbf{L}=\mathbf{N}+\mathbf{K} \text {, }
$$

де $\mathbf{N}$ - кількість інформаційних символів повідомлення; $\mathbf{K}$-кількість контрольних символів.

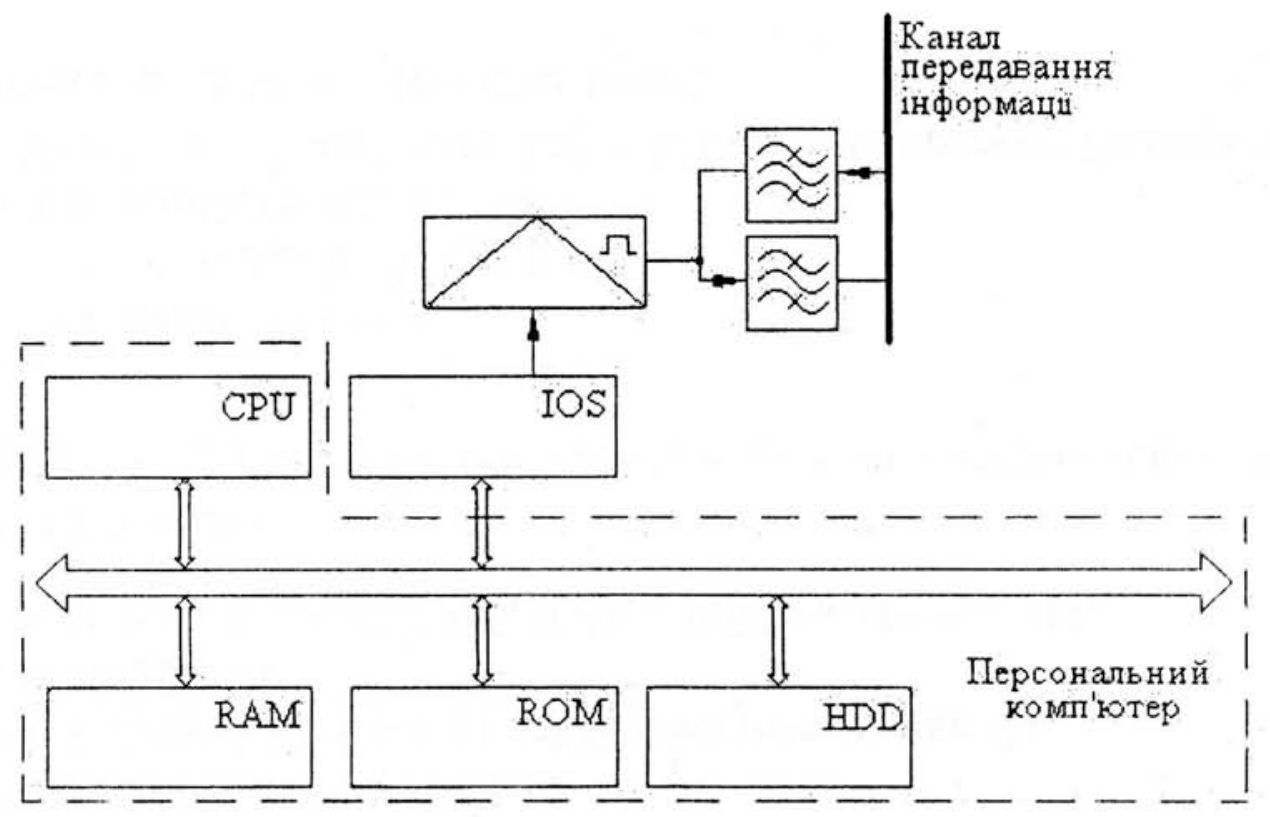

Рисунок 2 - Структура пристрою обміну інформацією

Під час передавання інформації суттєву роль відіграє спроможність коду визначати тә виправляти помилки, що в свою чергу залежить від кодової відстані. Для виправлення однієі помилки використовуються код Хеммінга, циклічний тощо. Проведений аналіз можливих варіантів формування кодових слів дозволяє визначити оптимальний 3 них при передаванні Е гих чи інших умовах. У випадку формування помилок пакетного типу необхіднс користуватись кодами іншого типу із більшою кодовою відстанню. Виходячи 3 цього. .дцільно будувати такий формат коду, щоб загальна кількість його розрядів була кратнок восьми, а кодова відстань була максимальною. При цьому код повинен бути нероздільним гобто у посиланні неможливо було б визначити інформаційні та контрольні розряди, щс надасть йому умови захищеності від несанкціонованого проникнення.

Найбільш ефективним за принципом завадозахищеності $€$ код 3 використанням фнкцій Уолша-Адамара, який має найбільшу кодову відстань d порівняно 3 іншими типам м.дів. Оскільки необхідною вимогою $є$ формування кодових комбінацій в байтовому форматі. то доцільно мати їх довжину у шістнадцять біт (два байти), що дозволяє отримать м.дову відстань:

$$
d=\frac{n}{2},
$$

* n - двжина кодової комбінації.

$$
d=\frac{16}{2}=8
$$


Така кодова відстань дозволяе виправляти три помилки, що для такої довжини кодової комбінації недосяжно для інших кодів. У відповідності із правилами побудови складається матриця Адамара, яка має вигляд:

$$
H_{16}=\left[\begin{array}{cccccccccccccccc}
1 & 1 & 1 & 1 & 1 & 1 & 1 & 1 & 1 & 1 & 1 & 1 & 1 & 1 & 1 & 1 \\
1 & -1 & 1 & -1 & 1 & -1 & 1 & -1 & 1 & -1 & 1 & -1 & 1 & -1 & 1 & -1 \\
1 & 1 & -1 & -1 & 1 & 1 & -1 & -1 & 1 & 1 & -1 & -1 & 1 & 1 & -1 & -1 \\
1 & -1 & -1 & 1 & 1 & -1 & -1 & 1 & 1 & -1 & -1 & 1 & 1 & -1 & -1 & 1 \\
1 & 1 & 1 & 1 & -1 & -1 & -1 & -1 & 1 & 1 & 1 & 1 & -1 & -1 & -1 & -1 \\
1 & -1 & 1 & -1 & -1 & 1 & -1 & 1 & 1 & -1 & 1 & -1 & -1 & 1 & -1 & 1 \\
1 & 1 & -1 & -1 & -1 & -1 & 1 & 1 & 1 & 1 & -1 & -1 & -1 & -1 & 1 & 1 \\
1 & -1 & -1 & 1 & -1 & 1 & 1 & -1 & 1 & -1 & -1 & 1 & -1 & 1 & 1 & -1 \\
1 & 1 & 1 & 1 & 1 & 1 & 1 & 1 & -1 & -1 & -1 & -1 & -1 & -1 & -1 & -1 \\
1 & -1 & 1 & -1 & 1 & -1 & 1 & -1 & -1 & 1 & -1 & 1 & -1 & 1 & -1 & 1 \\
1 & 1 & -1 & -1 & 1 & 1 & -1 & -1 & -1 & -1 & 1 & 1 & -1 & -1 & 1 & 1 \\
1 & -1 & -1 & 1 & 1 & -1 & -1 & 1 & -1 & 1 & 1 & -1 & -1 & 1 & 1 & -1 \\
1 & 1 & 1 & 1 & -1 & -1 & -1 & -1 & -1 & -1 & -1 & -1 & 1 & 1 & 1 & 1 \\
1 & -1 & 1 & -1 & -1 & 1 & -1 & 1 & -1 & 1 & -1 & 1 & 1 & -1 & 1 & -1 \\
1 & 1 & -1 & -1 & -1 & -1 & 1 & 1 & -1 & -1 & 1 & 1 & 1 & 1 & -1 & -1 \\
1 & -1 & -1 & 1 & -1 & 1 & 1 & -1 & -1 & 1 & 1 & -1 & 1 & -1 & -1 & 1
\end{array}\right]
$$

Приклад таблиці відповідності між кодовими комбінаціями та інформаційними повідомленнями

\begin{tabular}{|c|c|c|}
\hline $\begin{array}{r}\text { Інформац } \\
\text { ійне повідомлення }\end{array}$ & $=$ & Кодова комбінація \\
\hline 00000 & & 1111111111111111 \\
\hline 00001 & & 1010101010101010 \\
\hline 00010 & & 1100110011001100 \\
\hline 00011 & & 1001100110011001 \\
\hline 00100 & & 1111000011110000 \\
\hline 00101 & & 1010010110100101 \\
\hline 00110 & & 1100001111000011 \\
\hline 00111 & & 1001011010010110 \\
\hline 01000 & & 1111111100000000 \\
\hline 01001 & & 1010101001010101 \\
\hline 01010 & 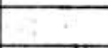 & 1100110000110011 \\
\hline 01011 & 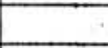 & 1001100101100110 \\
\hline 01100 & $\therefore$ & 1111000000001111 \\
\hline 01101 & & 1010010101011010 \\
\hline 01110 & & 1100001100111100 \\
\hline 01111 & & 1001011001101001 \\
\hline 10000 & & 0000000000000000 \\
\hline 10001 & & 0101010101010101 \\
\hline 10010 & 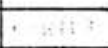 & 0011001100110011 \\
\hline 10011 & . & 01100110011001101, \\
\hline 10100 & 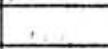 & 0000111100001111 \\
\hline 10101 & & 0101101001011010 \\
\hline 10110 & & 0011110000111100 \\
\hline 10111 & & 0110100101101001 \\
\hline 11000 & & 0000000011111111 \\
\hline 11001 & & 0101010110101010 \\
\hline 11010 & & 0011001111001100 \\
\hline 11011 & & 0110011010011001 \\
\hline 11100 & & 00001111111110000 \\
\hline 11101 & & 0101101010100101 \\
\hline 11110 & . & 0011110011000011 \\
\hline 11111 & & 0110100110010110 \\
\hline
\end{tabular}

Замінивши в рядках матриці $(-1)$ на нуль можна отримати перші шістнадцять кодових комбінацій, а потім проінвертувавши їх, можна отримати додаткові шістнадцять кодових комбінацій. Ним у відповідність можна поставити тридцять дві інформаційні кодові комбінації, наприклад як це подано у таблиці. Таблиця відповідності може складатися випадково, що дозволяе досягти однозначності між інформа-ційними повідомленнями та кодовими комбінаціями лише для того, хто цю таблицю складав i для того сеансу обміну інформацією, де вона використовується.

Передавання інформації може здійснюватися в синхронному чи : асинхронному режимі 3 використанням послідовних інтерфейсів, прий-мачівпередавачів або інших програмноапаратних засобів. Протокол, режим передавання та швидкість визначаються зов-нішніми чинниками i на процес кодування не впливають. Реалізація може здійснюватися для режиму програмного обміну інформацією 
чи для режиму переривань, кожний з яких має певні переваги та недоліки.

Використання послідовних універсальних приймачів-передавачів вимагає розбит кодової комбінації на два байти і окремого їх передавання. На приймальному боці прийн: байти парами об'єднуються в єдину кодову комбінацію, яка порівнюється 3 таблиц ӧазових. Якщо помилок під час передавання не виникло, то інформативне повідомлен може бути визначене одразу. У випадку виникнення помилок передавання, кодо комбінація має бути виправлена. Найбільш простим варіантом декодування є порівняння бітах отриманої кодової комбінації з базовими і вибір тієї, яка найбільше відповід отриманій. Цей принцип досить легко алгоритмізується і може реалізовуватись су програмним шляхом без будь-яких апаратних витрат 3 використанням класичю мікропроцесорної структури, поданої на рисунку 2. Програмне забезпечення д приймальної та передавальної частини пристрою можна розроблювати у відповідності схемами, наведеними відповідно на рисунках 3 та 4.
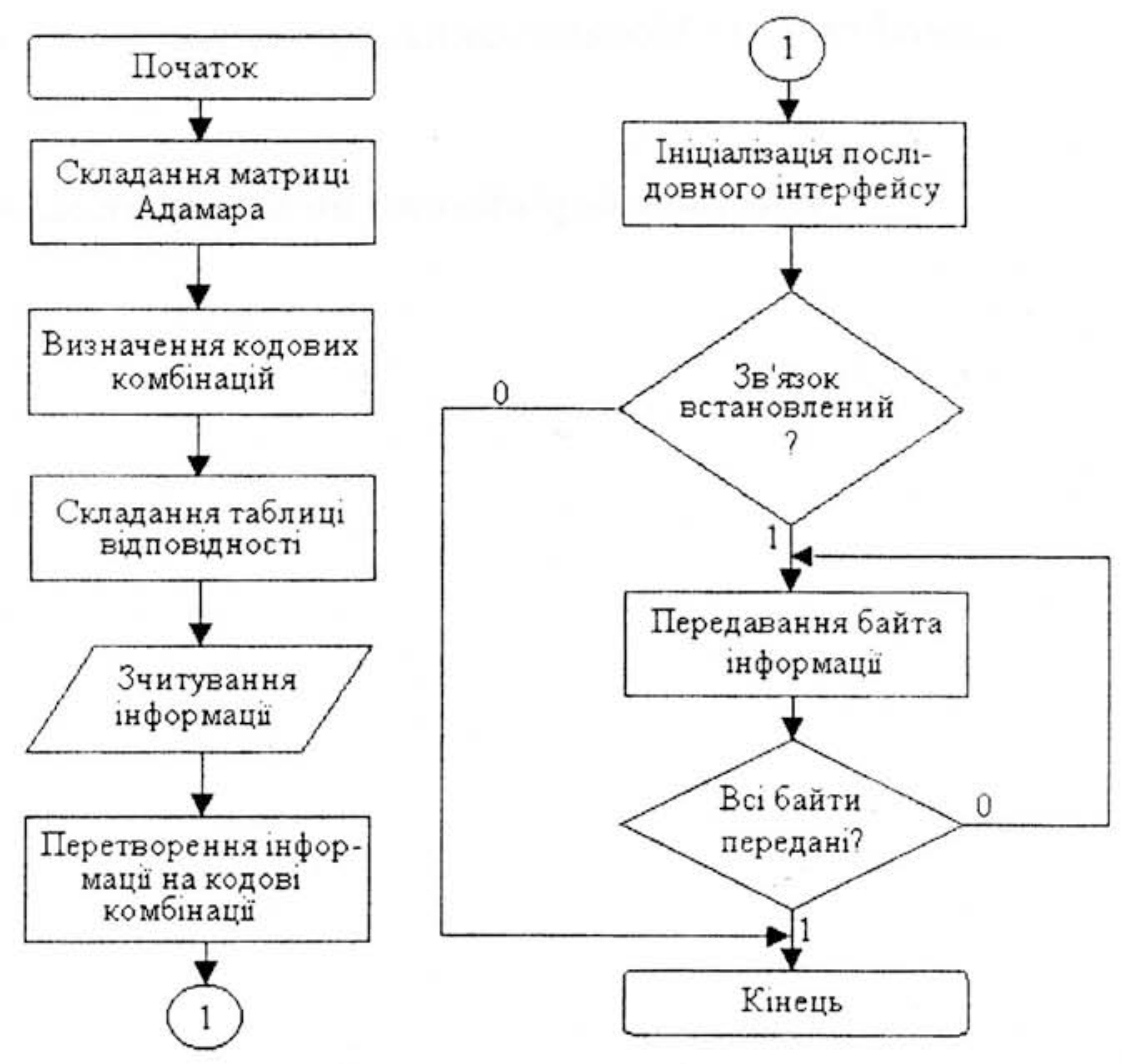

Рисунок 3 - Схема програмного забезпечення передавача

Апаратна реалізація кодувальних та декодувальних пристроїв за класични аямпиипом побудови вимагає розташування контрольних символів у кодовій комбінації н шхыс. номер розряду якого відповідає степені двійки. Це дозволяє зразу отримати номе рая. в якому виникла помилка. Але по-перше це здійснюється лише для виправлень a.2u: помилки, а по-друге суттєво знижує криптографічну стійкість коду, оскільк

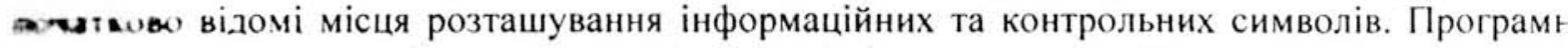

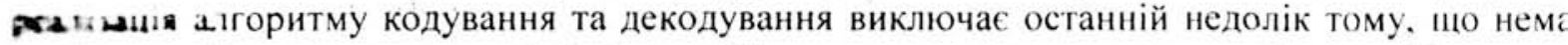
-cacmil ! розташуванні інформаційних та контрольних розрядів на фіксовани a 1 в вже вилучає однозначність кодової комбінації і допускає можливість реалізац anavioro диоритму перестановок. 
Запропонований алгоритм көдування, який базується на побудові матриці Адамара в принципі не вміщує інформаційних та контрольних символів, тобто є нероздільним. На відміну від алгоритмів Хеммінга та циклічного кодування, в цьому випадку доводиться оперувати не 3 окремими розрядами, а 3 цілими комбінаціями. Фактично, байти, що передаються не вміщують інформації. Класичні алгоритми криптографічного захисту інформації 3 таємним ключем (підстановки та комбінований) вимагають саме цього [5]. При реалізації розробленого алгоритму кодування інформацію вміщує послідовність байтів, що передаються, i таблиця відповідності, складання якої вже реалізує класичний алгоритм підстановки. Можливість перестановок кодових комбінацій у таблиці реалізує алгоритм перестановок. Тобто за своєю суттю розроблений алгоритм завадозахищеного кодування природно вміщує в собі класичний комбінований алгоритм криптографічного закриття інформації. Функцію таємного ключа в даному випадку виконує таблиця перекодування.

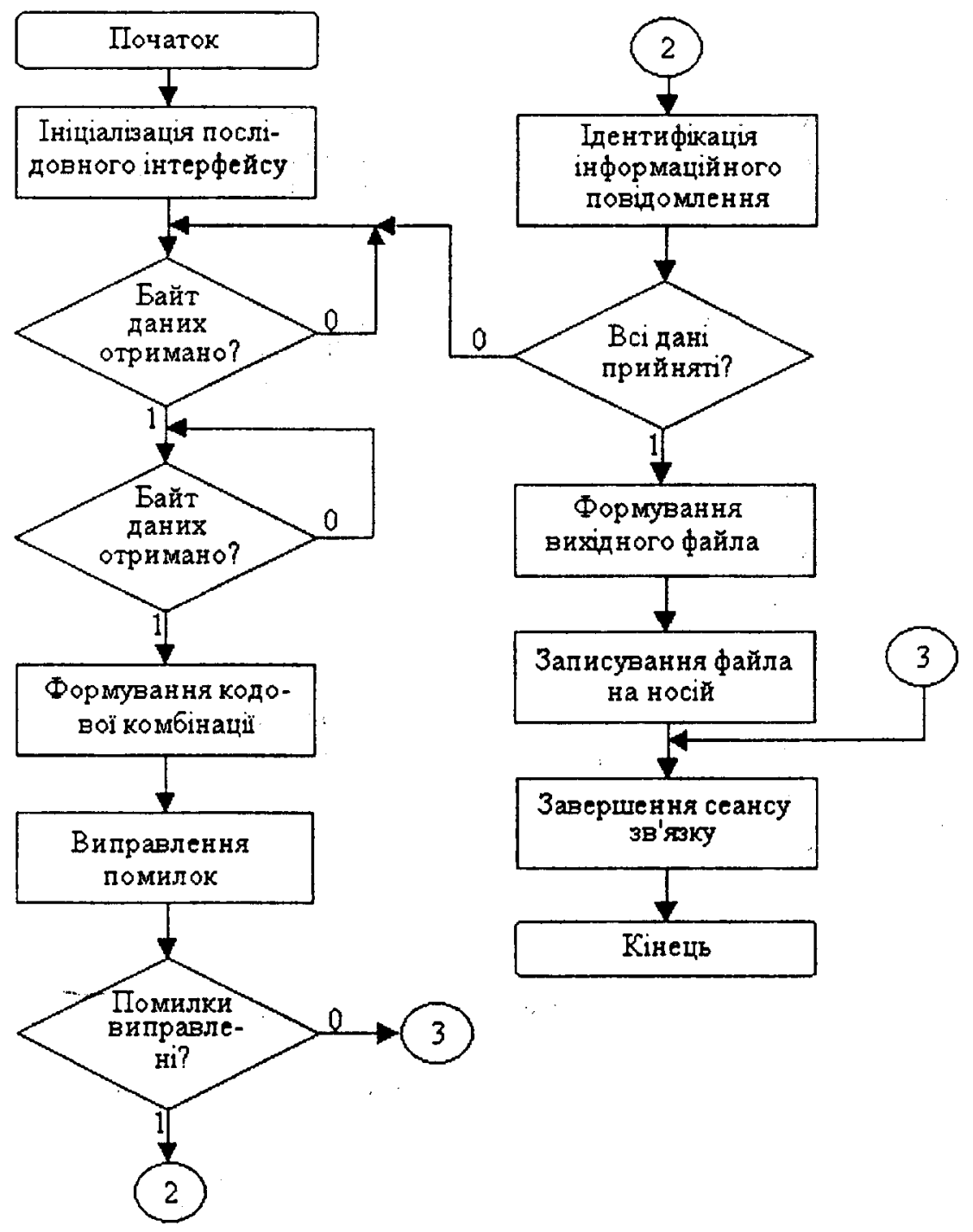

Рисунок 4 - Схема програмного забезпечення приймача 
Існує багато критеріїв визначення криптографічної стійкості алгоритмів закриття інформації, але найбільш об'єктивним є імовірнісний, який базується на визначенні кількості можливих переборів варіантів.

Кількість можливих варіантів перестановок комбінацій визначається формулою (4).

де $k_{k}$ - кількість кодових комбінацій.

$$
N_{k}=k_{k} \text { ! }
$$

Складена таблиця визначає відповідність між п'ятьма двійковими інформаційними розрядами та кодовими комбінаціями. Виходячи 3 цього, зчитану з носія інформацію, що має передаватися, необхідно розбити на інформаційні повідомлення по п'ять двійкових розрядів. Кількість можливих варіантів таких сполучень буде визначатися формулою (5).

$$
N_{n}=C_{8 . N}^{5}
$$

де $N-$ об'єм файла, що має передаватися, байт.

3 точки зору стороннього спостерігача, якому невідома таблиця відповідності між інформаційними повідомленнями і кодовими комбінаціями, встановлення цього зв'язку, тобто криптографічний аналіз повідомлення $є$ досить складною задачею. Повна кількість можливих варіантів перекодування складає:

$$
N_{\Sigma}=N_{k} \cdot N_{n}=k_{k} ! \cdot C_{8 \cdot N}^{5}=\frac{k_{k} ! \cdot(8 \cdot N) !}{5 ! \cdot(8 \cdot N-5) !}
$$

Навіть передавання 100 байт інформації за цим принципом для дешифрування вимагає, перебору $7 \cdot 10^{47}$ можливих варіантів, що показує досить високу криптостійкість даного способу.

При цьому немає необхідності реалізовувати два окремі алгоритми криптографічного закриття і завадозахищеного кодування, оскільки запропонований алгоритм виконує обидві функції.

\section{Список літератури}

1. Васюра А.С. та ін. Мікропроцесорні засоби передавання інформації. - Вінниця: ВдТУ, 1998. - $136 \mathrm{c}$.

2. Кривогубченко С.Г., Компанець М.М., Кулик А.Я. Особливості використання завадозахищених кодів для закриття інформації при передаванні колективними лініями з'язку // Збірник наукових праць Донецького державного технічного університету, серія -Еектротехніка і енергетика", 2000, № 17, с. 65 - 69 .

3. Кулик А.Я., Компанець М.М., Кривогубченко С.Г. Аналіз алгоритмів цмклічного кодування при передаванні інформації колективними лініями зв'язку // Збірник маукових праць Донецького державного технічного університету, серія "Обчислювальна гехніка та автоматика", 2000, № 20, с. 181 - 185.

4. Васюра А.С. та ін. Техніка передавання дискретної інформації. - Вінниця: Вдा', $1998-101 \mathrm{c}$.

5. Кулик А.Я. Використання інтерфейсних мікросхем при проектуванні шіхропроцесорних засобів автоматики. - Вінниця: ВДТУ, $1999-130$ с. 